\title{
A MARIA DA GRAÇA FERREIRA E A INVESTIGAÇÃO - ACÇÃO
}

No primeiro ano zero do Curso de Gestão e Desenvolvimento Social, em 1985/86, surgiu uma aluna que colocava bastantes perguntas no final da aula. A aluna em questão era a Graça Ferreira. Esta postura, embora não muito habitual na turma, fez com que surgisse uma realização de debates. Foi, a partir daqui, que, nos chamados seminários, passámos a ter um núcleo "duro" de colegas que animava os finais das aulas, com questões, que sugeriam a convidar actores (do foro económico, político, social e cultural) que falavam sobre determinado tema, logo animado pelas questões colocadas pelos alunos. $O$ grau de entusiasmo foi tal que, a partir do interesse manifestado por várias instituições e organizações, demos início à realização de diversos estudos. A componente teórica ficava a cargo do professor, mas a componente prática cedo passou a ser participada por alguns alunos, mesmo no período de férias.

Não resistimos a relatar um caso que aconteceu em pleno mês de Agosto de 1986. Um grupo de estudantes calcorreava os caminhos da Serra da Estrela para inquirir agricultores e pastores. Como a tarefa era árdua, conseguimos que os Serviços Florestais autorizassem que uma das casas perdidas na serra fosse dormitório da equipa. Os inquiridos eram acolhedores, mas as distâncias a vencer diariamente, a pé, eram consideráveis. Os estudantes perguntavam sempre: ainda estamos longe? O professor respondia: Não, é já aqui! Como esta frase se repetia inúmeras vezes, a Graça Ferreira resolveu baptizar o referido professor com a frase: "é já aqui!".

O saber que ela própria consolidava ao longo da sua formação, sempre com a dimensão teórico-prática, fez com que, ao terminar o curso, desse vários testemunhos na mesma linha de acção.

Na docência foi um exemplo. Treinava os alunos para as linhas teóricas, fazendo com que até fossem com ela para a biblioteca, bem como para a sua residência, a fim de compulsarem páginas e páginas de livros raros. No domínio dos trabalhos de campo lá ia a Graça com os alunos, ficando tantas vezes sem jantar e sem ceia, uma vez que, não raro, alguns trabalhos terminavam noite dentro. 
É claro que, de vez em quando, aparecia alguém, como num Domingo de Ramos, em que estando um grupo a trabalhar, lá fez chegar umas sandes - esse alguém foi o saudoso Monsenhor Celso. A essa generosidade, a Graça Ferreira respondeu: "o nosso pastor nunca se esquece das suas ovelhas".

Nas tarefas desenvolvidas no âmbito da Associação de Apoio ao Instituto Universitário de Desenvolvimento e Promoção Social, a Graça Ferreira foi uma obreira do seu crescimento. Nunca se recusou ao mais pequeno apelo, em qualquer período de tempo e em qualquer lugar do espaço.

Também não podemos deixar de anotar a frutuosa colaboração que nos deu nos seminários, onde a valência investigação-acção lhe foi sempre muito querida.

Nesta hora de relembrar memórias, só podemos dizer que foi: uma professora, uma investigadora, uma amiga, em suma, uma Mulher.

Sem a Graça Ferreira, esta terra já não é o que era.

Que a terra the seja leve!

Sabugueiro, Outubro 1997

Alberto Martinho 